\title{
Relationships of macrophyte species richness and environment in different water body types in the Central European region
}

\author{
Kateřina Bubíková ${ }^{1, *}$ and Richard Hrivnák ${ }^{2}$ \\ ${ }^{1}$ Water Research Institute, Nábrežie arm. gen. L. Svobodu 7, 81249 Bratislava, Slovakia \\ ${ }^{2}$ Institute of Botany, Plant Science and Biodiversity Center, Slovak Academy of Sciences, Dúbravská cesta 9, 84523 Bratislava, \\ Slovakia
}

Received: 18 April 2018; Accepted: 15 October 2018

\begin{abstract}
Individual types of waterbodies are characterised by their specific environmental conditions controlling growth of aquatic macrophytes. We focused on effects of environmental factors on macrophyte species richness in canals, ponds, rivers and streams within Central European region. We employed generalised linear models (GLM) to assess separately overall macrophyte species data and data on wetland species (true aquatic plants and helophytes). No significant difference was revealed by comparing species richness among water body types, though canals were the richest water bodies and streams supported the lowest diversity of macrophytes. The models for all the waterbodies, except streams, contained at least two variables and the explained variability ranged from $37 \%$ to $77 \%$. The most recurring variables were the coverage of fine substrate, turbidity, shading by bank and shore trees and shrubs, and altitude. Nevertheless, no obvious pattern of factors was observed for particular water body types. Our study confirmed that aquatic macrophyte species richness is shaped by a complexity of factors and necessity of targeting survey and further generalisation of results not only on one specific water body.
\end{abstract}

Keywords: Environmental effects / generalised linear models / local diversity / aquatic plants / Slovakia

\section{Introduction}

Influence of environmental factors explaining shaping of macrophyte diversity has been studied for a long time (Lacoul and Freedman, 2006; Stendera et al., 2012). Such kind of information is a key component in effective management and protection of freshwaters which belong to the most threatened habitats in the world (Dudgeon et al., 2006). Freshwater ecosystems are complex environments where the identification of the main vegetation diversity drivers could be slightly tricky from time to time not only due to synergistic effects of environmental factors but also because target groups of plants differ in their response to environmental variables. Aquatic plants include species with different life and growth forms; helophytes growing in the shallow littoral zone, non-rooted pleustophytes in water column or on the water surface, rooted submerged or emergent species. These species groups are influenced by different environmental factors (Toivonen and Huttunen, 1995; Edvardsen and Økland, 2006; Akasaka et al., 2010; Alahuhta et al., 2014) which could cause difficulties in the assessment and generalisation of the diversityenvironment relationship.

\footnotetext{
*Corresponding author: katka.bubikova@gmail.com
}

Light availability is a fundamental condition for all plant species. In aquatic ecosystems, penetration of light is driven by water transparency affected by several factors like shading by bank and shore vegetation, occurrence of phytoplankton, farming of bottom-dwelling fish or by vegetation itself (Crivelli, 1983; Sand-Jensen and Borum, 1991; Weisner et al., 1997; Welch et al., 2003; Lacoul and Freedman, 2006). Indirectly, also the surrounding landscape can impact the transparency and influence diversity. Arable fields and inhabited areas in the catchment of water bodies increase nitrogen and phosphorus influx into freshwaters which could lead e.g. to a higher abundance of phytoplankton (Scheffer et al., 1993; Carpenter et al., 1998; Hilli et al., 2007; Akasaka et al., 2010).

Water current is considered as another significant driver of macrophyte diversity in freshwaters (Lacoul and Freedman, 2006; Bornette and Puijalon, 2011). Only plants with proper morphological adaptations like streamlined shapes, strap-like leaves or flat shoots are able to grow in a current. The optimum range for a high local diversity is $30-40 \mathrm{~cm} \mathrm{~s}^{-1}$, velocity above $100 \mathrm{~cm} \mathrm{~s}^{-1}$ pronouncedly decreases species richness (Chambers et al., 1991; Riis et al., 2003). Water movement influences species richness not only directly by the delimitation of some species from locality due to a high current 


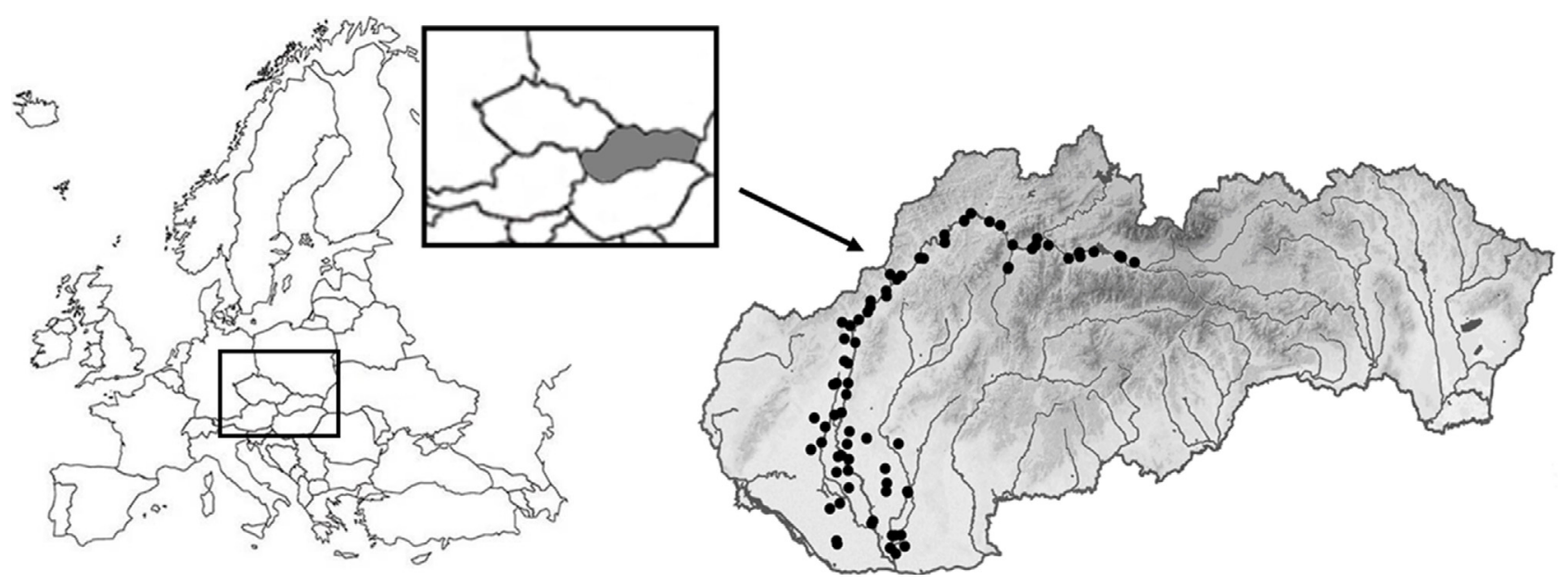

Fig. 1. Map showing the distribution of sampling sites.

velocity, but also through the impact on bottom substrate (e.g., scouring and deposition of sediments), or stream morphology (Haslam, 2006). Different substrate types and their modifications perform variously in shaping of macrophyte communities, especially assemblages of rooted plans (Baattrup-Pedersen and Riis, 1999).

Several other local and regional factors also influence aquatic macrophyte richness. Climatic factors, hydrological and physico-chemical characteristics, such as nutrients and trophic status, alkalinity and $\mathrm{pH}$, are frequently reported (Lacoul and Freedman, 2006; Bornette and Puijalon, 2011).

Many important factors are hidden in the surrounding landscape, which can be considered as a proxy factor useful for example in the interpretation of nutrient input resulting from human activities (Alahuhta et al., 2011; Varanka and Luoto, 2012; Alahuhta et al., 2014). Various types of water bodies differ in catchment size: small ponds have smaller catchments in comparison with rivers or streams (Davies et al., 2008) and naturally, also differ in the intensity of human activities.

Studies targeted on macrophytes-environment relationships either incline to one type of water body or investigate solely lotic or lentic habitats (e.g. Toivonen and Huttunen, 1995; Baattrup-Pedersen and Riis, 1999; Daniel et al., 2006). As stated above, the effect of environmental factors is complex and environmental variables differ in their importance among various water body types. Using a quite robust data set from Slovakia, we aim to identify environmental factors that affect local macrophyte diversity in four basic types of water bodies (canals, streams, rivers and ponds) in Central Europe.

\section{Methods}

\subsection{Study area and data sampling}

The study was conducted in the Váh river valley, from the confluence of the Biely Váh river and the Čierny Váh river to the inflow into the Danube river in total area $\sim 680 \mathrm{~km}^{2}$, with altitude ranging from 106 to $662 \mathrm{~m}$ a.s.l. Study area was defined as a zone of 30 altitude meters from the Váh river watercourse. The studied area was situated in two bioregions, the Western Carpathian (in further text referred to as the
Carpathian) and the Pannonian. Landscape of the downstream area was created predominantly by agricultural and urban areas, while forests dominated in upstream areas. Geological and soil substrates were rather unified; with prevalence of Quaternary alluvial soils, and floodplain sands and gravel soils. However, the tributaries of the Váh River flow from areas of various geological units and differ in catchment geology (Miklós, 2002).

Our research was conducted during the vegetation season of 2014. We distinguished four water body types: rivers, stream, canals and ponds, according to the methodology of Williams et al. (2004). We defined ponds as lentic habitats with an area in the range of $0.05-5$ ha, of both natural (e.g. oxbow ponds) and artificial (e.g. fishponds, gravel pits) origin. For each water body type, 25 localities were selected, with emphasis on equal distribution throughout the entire survey area. Altogether, 100 localities were sampled (Fig. 1). The sampling area $\left(100 \mathrm{~m}^{2}\right.$ at each sampling site) of lotic habitats was determined as length $\times$ width of the water course, with a minimum width of $0.5 \mathrm{~m}$. In ponds, the $100 \mathrm{~m}^{2}$ sampling area was triangular with the base on the margin and the apex at the centre of the locality (Williams et al., 2004; Bubíková and Hrivnák, 2018). At each locality, all macrophytes (including filamentous algae, stoneworts, bryophytes and vascular plants) were recorded by wading or from boat (depending on the waterbody depth). Nomenclature of plant species is in accordance with the checklist of Marhold and Hindák (1998).

Physicochemical, hydrological and land use variables were recorded at each site. Water conductivity, $\mathrm{pH}$, temperature and dissolved oxygen were measured directly in the field by the portable CyberScan PC 650 and Eutech DO 6+ devices, respectively. Altitude was recorded by a Garmin GPS device. Average water depth was calculated on the basis of 10 randomly selected measurements within the locality. To evaluate potential effect of shading by riparian vegetation, percentage cover of shrubs and trees on shores and banks (farther only banks) higher than three metres was estimated at each site. Percentage proportion of five categories of land use ((1) forests and bushes, (2) wetlands, (3) pastures, meadows and orchards, (4) arable land and (5) urban areas including industrial zones) was estimated within $100 \mathrm{~m}$ diameter or belt 
from the water bodies. Flow velocity was defined on four levels scale $\left(1=\right.$ standing water to $4=$ faster than $\left.65 \mathrm{~cm} \mathrm{~s}^{-1}\right)$. Turbidity was estimated on three levels scale from visibility more than $40 \mathrm{~cm}$ (1) to visibility less than $30 \mathrm{~cm} \mathrm{(3).}$ Hydrological regime was estimated on the scale from 1 to 4 $(1=$ permanently waterlogged to $4=$ drying every year). Bank slope was visually estimated as gradual or steep with threshold $20^{\circ}$. Water samples consisting of three spatially stratified replicates $(100 \mathrm{ml})$ were collected at each site, quickly frozen and taken to laboratory for further analysis of ammonium nitrogen $\left(\mathrm{NH}_{4}^{+}\right)$, nitrate nitrogen $\left(\mathrm{NO}_{3}^{-}\right)$, nitrite nitrogen $\left(\mathrm{NO}_{2}^{-}\right)$and orthophosphate content $\left(\mathrm{PO}_{4}^{3-}\right)$ according to the methodology used in Hrivnák et al. (2013). To reduce seasonality, measurements of water conductivity, $\mathrm{pH}$, temperature, oxygen and nutrient content were repeated in September. Mean values based on two measurements were used for the analysis (see also Bubíková and Hrivnák, 2018).

\subsection{Data analyses}

The species occurrence data were split into two presence/ absence matrices with the exclusion of filamentous algae. The first matrix was composed of all observed species, the second of true aquatic species (hydrophytes) and helophytes (hereafter referred as wetland species). Distinction of helophytes and hydrophytes was based on previous studies (Alahuhta et al., 2012; Landucci et al., 2015; Kolada, 2016). Localities with no macrophytes recorded were excluded from datasets and further analyses (22 and 24 localities for all and wetland species, respectively).

We assessed relationships between pairs of variables by non-parametric Spearman's correlation coefficient to exclude potentially highly correlated $(r>0.7)$ variables. Based on the results, we excluded cover of coarse substrate only.

Variables were transformed for improving homoscedasticity where necessary. Log transformation was used for altitude, water depth and water conductivity; arcsine-square root transformation was applied on percentage values with percentage cover (shading, types of substrate and land use); for water content of $\mathrm{NH}_{4}^{+}, \mathrm{NO}_{3}^{-}, \mathrm{NO}_{2}^{-}$and $\mathrm{PO}_{4}^{-}$, cube root transformation was used.

Local $(\alpha)$ diversity was defined as the raw species number recorded at sampling site. For testing possible differences in species richness among water body types we ran one-way ANOVA. First, we conducted the Bartlett test for checking the homogeneity of variances. Due to non-normality of the dataset, permutational ANOVA was applied on both matrices.

Local diversity was modelled separately for each species group and each type of habitat (altogether 8 models) and for both species groups and all type of habitats together ( 2 models) using generalised linear models (GLM) with an assumed Poisson distribution and log link function (McCullagh and Nelder, 1989). Automated model selection function with the small-sample corrected AIC was applied to obtain the best model (Calgano and Mazancourt, 2010).

Analyses were performed in $\mathrm{R}$ software ( $\mathrm{R}$ development core team, 2016), using the libraries vegan (Oksanen et al., 2016), lmPerm (Wheeler and Torchiano, 2016) and glmulti (Calcagno, 2013). Results were considered as significant at $\alpha=95 \%$.

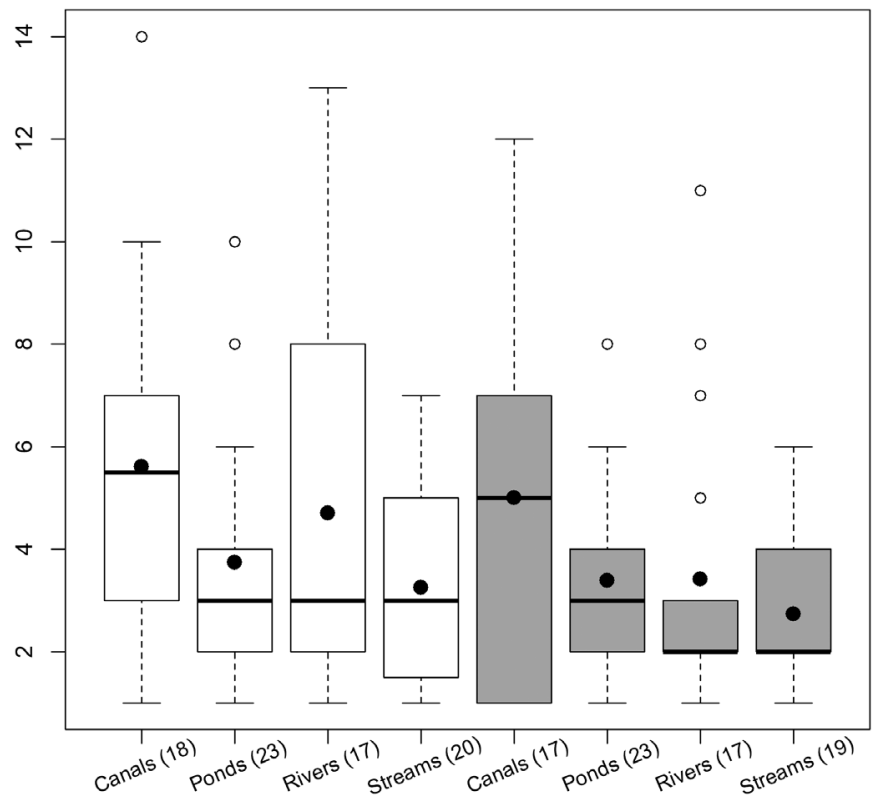

Fig 2. Summary of macrophyte species richness and number of localities of water body types. White box plots represent all species, grey box plots represent wetland species. Lines and filled circles show median and mean values, respectively.

\section{Results}

\subsection{Local diversity of localities and environmental characteristics}

Altogether, 84 species were found and 53 classified as wetland species with mean values per locality 4.3 and 3.6 for all and wetland species, respectively. Canals were the waterbodies richest in species for both groups (all species group mean $=5.6$; wetland species mean $=5.0$ ) (Fig. 2). Nevertheless, permutational ANOVA did not yield any significant difference of $\alpha$-diversity among water body types ( $p$-values were 0.08 and 0.06 for all and wetland species group, respectively).

Localities were similar in terms of mean $\mathrm{pH}$, temperature, content of oxygen, nitrite nitrogen and orthophosphate. Water bodies were characterised by middle turbidity with prevailing fine substrate in bottom, and fields together with artificial landscape were types of land use with highest percentage cover in vicinity of water bodies. On average, the deepest water bodies were ponds, and this habitat also showed the highest shading by riparian vegetation. Streams showed the highest conductivity, percentage cover of artificial land use and the lowest water depth (Tab. 1).

\subsection{Environmental drivers of local diversity}

GLM models with range of explained variability from $37.8 \%$ to $77.6 \%$ and with two variables at least were obtained for all types of water bodies and both species groups (with the exception of $\alpha$-diversity of wetland species in streams) (Tabs. 2, 3). No obvious pattern of common environmental factors was observed for particular water body types. The 
Table 1. Summary characteristics of environmental variables with abbreviations used in further text. Mean values with range (in brackets) are displayed.

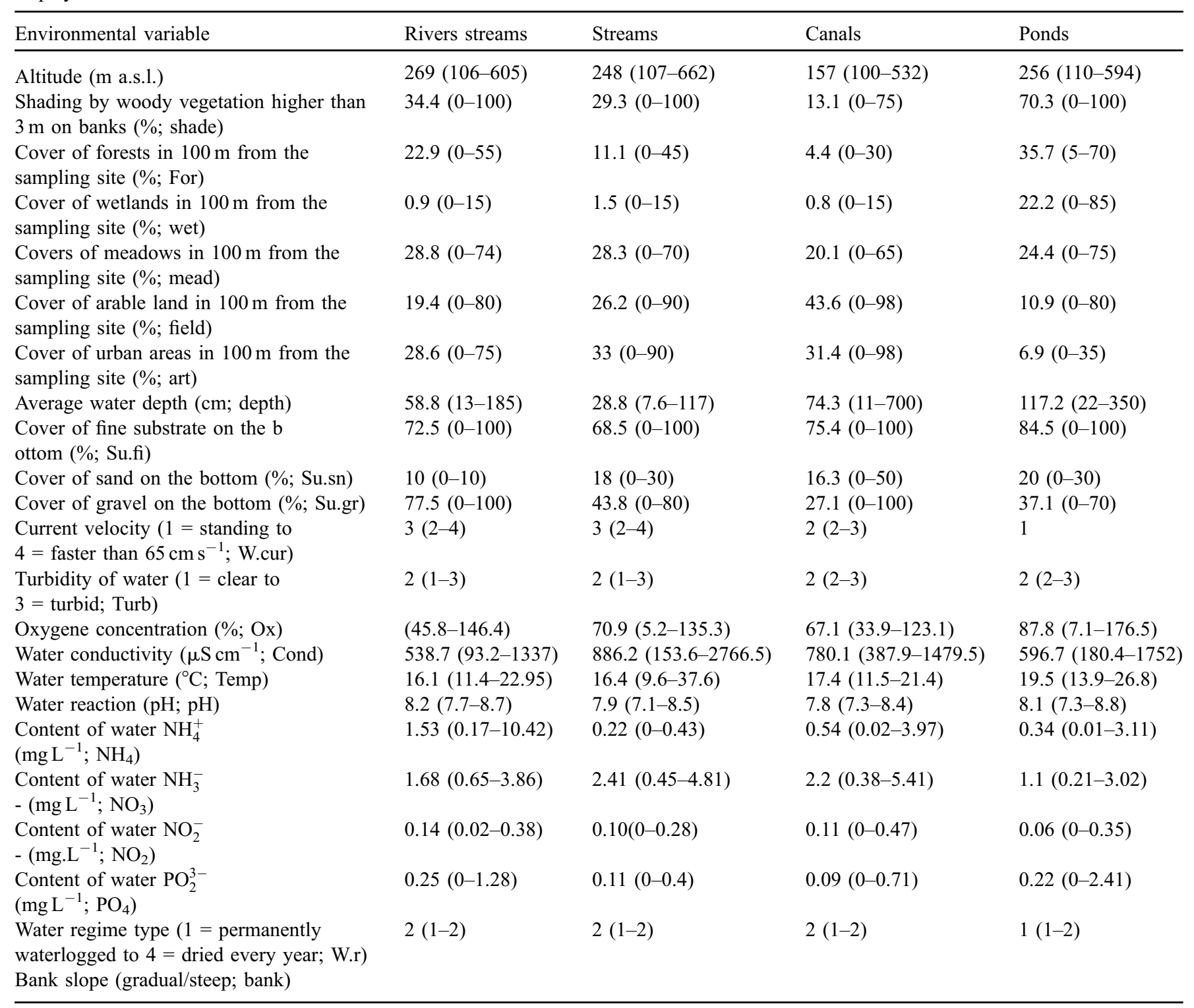

model with the highest explained variability included the combination of altitude, forests land use, turbidity and $\mathrm{pH}$ and was obtained for wetland species in rivers. The model with the lowest explained variability consisted of fine substrate and turbidity and was obtained for all species in rivers. The most recurrent variables were the cover of fine substrate, turbidity and shading (occurred in 5 models) and altitude (4 models); fine substrate affected $\alpha$-diversity positively, turbidity and altitude negatively and shading had negative effect with exception of $\alpha$-diversity of all species in ponds.

\section{Discussion}

Our study was targeted on assessing and comparing the local diversity and environmental variables in different water body types. GLM revealed influence of altitude, shade and coverage of fine substrate as the most common factors affecting macrophyte species richness. Our results are in accordance with previous studies (see Lacoul and Freedman, 2006; Bornette and Puijalon, 2011). Anyway, we found some interesting results. First, shading by shore vegetation had positive influence for overall species richness in ponds. It is quite surprising because unfavourable light conditions commonly decrease macrophyte growth (Barko et al., 1986; Grinberga, 2011; Riis et al., 2012). Moreover, shrubs and trees on shores can serve as a barrier for plant propagules intrusion and they also support input of leaf litter which is known to decrease macrophyte richness (Barko and Smart, 1983). However, light conditions of larger ponds ( $>1$ ha, $65 \%$ of localities) in our study were probably not deteriorated by shrubs and trees on the shores. Shading by shore vegetation had no direct effect on the entire area of the ponds. Thus, we 
Table 2. Final models obtained in GLM explaining macrophyte species richness in water body types and for species groups with explained percent variability $(V \%)$. Signs "+" and "_" indicate positive or negative effect on species richness, respectively. Abbreviations are presented in Table 1.

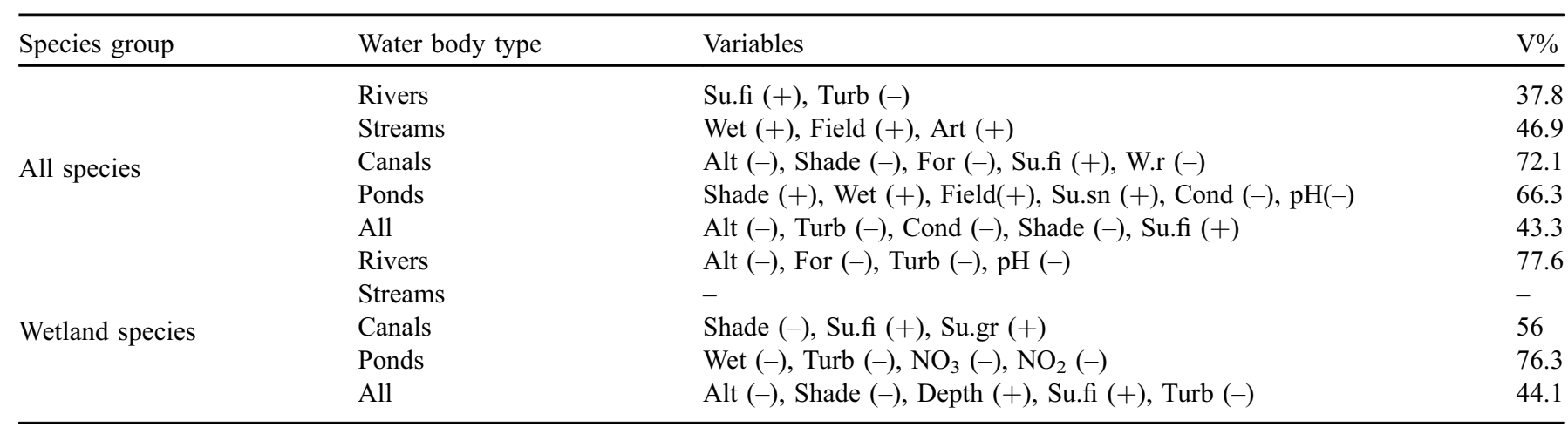

Table 3. Estimated parameters (Coef - estimated coefficients, SE - coefficient standard error) from final models obtained by GLM. Variables abbreviations are explained in Table 1. Asterisks indicate statistically significant results $(* p<0.05, * * p<0.01, * * * p<0.001)$.

\begin{tabular}{|c|c|c|c|c|c|c|c|c|c|c|c|}
\hline Variable & \multicolumn{2}{|c|}{ Rivers } & \multicolumn{2}{|c|}{ Streams } & \multicolumn{2}{|c|}{ Canals } & \multicolumn{3}{|c|}{ Ponds } & \multicolumn{2}{|c|}{ All } \\
\hline \multicolumn{12}{|c|}{ All species } \\
\hline Turb & $-0.445^{* *}$ & 0.159 & & & & & & & & $-0.459^{* * *}$ & 0.102 \\
\hline Wet & & & $2.276^{*}$ & 1.107 & & & $1.091^{*}$ & & & & \\
\hline Field & & & $1.241^{* *}$ & 0.432 & & & $1.654^{* * *}$ & & & & \\
\hline Alt & & & & & $-0.988^{*}$ & 0.462 & & & & $-0.584^{* * *}$ & 0.136 \\
\hline Shade & & & & & -0.847 & 0.446 & $0.853^{*}$ & & 0.380 & $-0.337^{* *}$ & 0.107 \\
\hline For & & & & & -1.003 & 0.742 & & & & & \\
\hline W.reg & & & & & -0.269 & 0.238 & & & & & \\
\hline Su.sn & & & & & & & 1.675 & & 1.050 & & \\
\hline Cond & & & & & & & $-1.325^{* * *}$ & & 0.402 & & \\
\hline Alt & $-0.956^{* * *}$ & 0.257 & & & & & & & $-0.493^{* * *}$ & 0.139 & \\
\hline Shade & & & & & $-1.295^{* *}$ & 0.502 & & & $-0.271^{*}$ & 0.118 & \\
\hline For & -0.668 & 0.499 & & & & & & & & & \\
\hline $\mathrm{pH}$ & $-1.011^{*}$ & 0.486 & & & & & & & & & \\
\hline Turb & -0.300 & 0.193 & & & & & $-1.018^{* *}$ & 0.343 & $-0.381^{* * *}$ & 0.112 & \\
\hline Su.gr & & & & & $0.768^{* *}$ & 0.278 & $/ 1$ & & & & \\
\hline $\mathrm{NO}_{3}$ & & & & & & & $-1.641^{*}$ & 0.652 & & & \\
\hline $\mathrm{NO}_{2}$ & & & & & & & $1.672^{*}$ & 0.812 & & & \\
\hline Depth & & & & & & & & & $0.151^{*}$ & 0.070 & \\
\hline
\end{tabular}

assume that diversified light conditions enabled occurrence of macrophytes with different light requirements and lead to positive effect of shading on macrophyte richness.

Second, positive effect of surrounding arable land or artificial land appeared in two models. Several previous studies showed opposite, negative effect (or positive but statistically non-significant) of artificial surfaces on aquatic macrophyte richness (Akasaka et al., 2010; Svitok et al., 2016). Human activities usually lead to a decrease of water quality as a consequence of higher nutrient and pollution input
(Søndergaard et al., 2005; Sand-Jensen et al., 2008; Kolada, 2010; Lauridsen et al., 2015). However, spatial scale for evaluation of land use in surroundings of water bodies is important for understanding the effects on water body environment. For example, Novikmec et al. (2016) showed that the catchment-scale land use was a significant spatial scale influencing the physicochemical conditions, while the landscape in immediate surroundings had lower impact. In addition, the relevant spatial extent of land use also varies across growth forms of macrophytes (Akasaka et al., 2010). 
Thus, positive effect of artificial surfaces found in our study could result from land use characteristics within broader surroundings (e.g. larger spatial scale) of the ponds.

Positive effect of depth obtained in the model for wetland species in all water body types was also a remarkable result. Sufficient light radiance, a crucial factor for the development of macrophyte stands, often becomes deteriorated by depth, though greater depth does not automatically mean worse light conditions (Lacoul and Freedman, 2006). However, it is difficult to define the maximal water depth suitable for macrophyte growth. According to Canfield et al. (1985) the predictable depth is roughly expressed as double or treble of the transparency measured by Secchi disc. Resuspension of fine bottom sediment, occurrence of phytoplankton or bottom dwelling fish, and shading by bank and shore vegetation also deteriorate light conditions at the locality.

Even though we studied three lotic water body types, no influence of water current was recorded. The only significant factor related to water movement was unstable water regime found in canals for the model with all species. Fluctuating water level has well known effect on macrophytes (Hill et al., 1998; Dienst et al., 2004; Krolová et al., 2013). However, richness of both studied species groups was very similar to each other (5.6 and 5 species, respectively) in canals, thus it is quite interesting that in the model for wetland species water regime did not perform as significant. Moreover, incidentally occurred non-wetland species were included in the group of all species $\mathrm{s}$ and one would expect that seasonal drying could support these species. Lower water level enhances germination of spores and enables development of the vegetation of exposed bottoms (Havens et al., 2004; Deil 2005). Thus, the decline of species richness was probably caused by a harmful effect of substrate erosion caused by water movements (Furey et al., 2004).

Freshwater habitats connected to each other or in the proximity to other wetland habitats are characterised by higher $\alpha$ and $\gamma$ diversities (Akasaka and Takamura, 2012). Model for all species in ponds supported this statement. However, for the same water body type, effect on wetland species was surprisingly negative.

\section{Conclusions}

Our results confirmed that environmental factors affect macrophyte local diversity in a complex way. In final models obtained by GLM several local variables such as light availability, physico-chemical (water $\mathrm{pH}$, water conductivity, turbidity and nutrients), geomorphological (type of bottom substrate, water depth) and regional (surrounding landscape, altitude) factors were included in different combination for specific water body. We also found that factors influencing macrophyte diversity within one water body type could be different if different species groups were taken into account. To preserve macrophyte richness in Central European landscape it is important to take into account not only specific type of water body but the whole possible scale of freshwater habitats within the area of interest. It seems that all the water body types contribute similarly to the total macrophyte richness. Therefore, knowledge on factors that shape macrophyte richness in all the individual types of freshwaters is important.
Acknowledgement. We would like to thank Judita Kochjarová and Barbara Immerová for their assistance during the field work and to Milan Novikmec, Dušan Gömöry and three anonymous reviewers for useful and improving comments. This study was supported by the Slovak Research and Development Agency under contract No. APVV-16-0236 and VEGA 2/0030/17.

\section{References}

Akasaka M, Takamura N, Mitsuhashi H, Kadono Y. 2010. Effects of land use on aquatic macrophyte diversity and water quality of ponds. Freshwater Biol 55: 909-922.

Akasaka M, Takamura N. 2012. Hydrologic connection between ponds positively affects macrophyte $\alpha$ and $\gamma$ diversity but negatively affects $\beta$ diversity. Ecology 93: 967-973.

Alahuhta J, Vuori K-M, Luoto M. 2011. Land use, geomorphology and climate as environmental determinants of emergent aquatic macrophytes in boreal catchments. Boreal Environ Res 16: 185-202.

Alahuhta J, Kanninen A, Vuori K-M. 2012. Response of macrophyte communities and status metrics to natural gradients and land use in boreal lakes. Aquat Bot 103: 106-114.

Alahuhta J, Kaninen A, Hellsten S, Vuori K-M, Kuoppala M, Hämäläinen H. 2014. Variable response of functional macrophyte groups to lake characteristics, land use, and space: implications for bioassessment. Hydrobiologia 737: 201-214.

Baattrup-Pedersen A, Riis T. 1999. Macrophyte diversity and composition in relation to substratum characteristics in regulated and unregulated Danish streams. Freshw Biol 42: 375-385.

Barko JW, Smart RM. 1983. Effects of organic matter additions to sediment on the growth of aquatic plants. $J$ Ecol 71: 161-175.

Barko JW, Adams MS, Clesceri NL. 1986. Environmental factors and their consideration in the management of submersed aquatic vegetation: a review. J Aquat Plant Manage 24: 1-10.

Bornette G, Puijalon S. 2011. Response of aquatic plants to abiotic factors: a review. Aquat Sci 73: 1-14.

Bubíková K, Hrivnák R. 2018. Comparative macrophyte diversity of waterbodies in the Central European landscape. Wetlands 38: 451-459.

Calgano V, Mazancourt C. 2010. glmulti: An R package for easy automated model selection with (generalized) linear models. J Stat Softw 34: 12.

Calcagno V. 2013. glmulti: Model selection and multimodel inference made easy. $R$ package version 1.0.7. http://CRAN.R-project.org/ package $=$ glmulti.

Canfield DE, Langeland KA, Linda SB, Haller WT. 1985. Relation between water transparency and maximum depth of macrophyte colonization in lakes. J Aquat Plant Manag 23: 25-28.

Carpenter SR, Caraco NF, Correl DL, Howarth RW, Sharpley AN, Smith VH. 1998. Nonpoint pollution of surface waters with phosphorus and nitrogen. Ecol Appl. 8: 559-568.

Chambers PA, Prepas EE, Hamilton HR, Bothwell ML. 1991. Current velocity and its effect on aquatic macrophytes in flowing waters. Ecol Appl 1: 249-257.

Crivelli AJ. 1983. The destruction of aquatic vegetation by carp. Hydrobiologia 106: 37-41.

Daniel H, Bernez I, Haury J. 2006. Relationships between macrophytic vegetation and physical features of river habitats: the need for a morphological approach. Hydrobiologia 570: 11-17.

Davies BR, Biggs J, Williams PJ, Lee JT, Thompson S. 2008. A comparison of the catchment sizes of rivers, streams, ponds, ditches and lakes: implications for protecting aquatic biodiversity in an agricultural landscape. Hydrobiologia 597: 7-17. 
Deil U. 2005. A review on habitats, plant traits and vegetation of ephemeral wetlands - a global perspective. Phytocoenologia 35: 533-705.

Dienst M, Schmieder K, Ostendorp W. 2004. Effects of water level variations on the dynamics of the reed belts of Lake Constance. Limnologica 34: 29-36.

Dudgeon D, Arthington AH, Gessner MO, Kawabata ZI, Knowler DJ, Léveque C, Naiman RJ, Prieur-Richard AH, Soto D, Stiassny MLJ, Sullivan CA. 2006. Freshwater biodiversity: importance, threats, status and conservation challenges. Biol Rev 81: 163-182.

Edvardsen A, Økland RH. 2006. Variation in plant species composition in and adjacent to 64 ponds in SE Norwegian agricultural landscapes. Aquat Bot. 85: 92-102.

Furey PC, Nordin RN, Mazumder A. 2004. Water level drawdown affects physical and biogeochemical properties of littoral sediments of a reservoir and a natural lake. Lake Reserv Manag 20: 280-295.

Grinberga L. 2011. Macrophyte species composition in streams of Latvia under different flow and substrate conditions. Estonian $J$ Ecol 60: 194-208.

Haslam SM. 2006. River Plants. Cambridge: Cambridge University Press, $438 \mathrm{p}$.

Havens KE, Sharfstein B, Brady MA, East TL, Harwell MC, Maki RP, Rodusky AJ. 2004. Recovery of submerged plants from high water stress in a large subtropical lake in Florida, USA. Aquat Bot 78: 6782.

Hill NM, Keddy PA, Wisheu IC. 1998. A hydrological model for predicting the effects of dams on the shoreline vegetation of lakes and reservoirs. Environ Manage 22: 723-736.

Hilli M, Kuitunen MT, Suhonen J. 2007. The effects of land use change on the vascular plant species turnover in boreal lakes. Biodivers Conserv 16: 3951-3962.

Hrivnák R, Otahel’ová H, Kochjarová J, Pal'ove-Balang P. 2013. Effect of environmental conditions on species composition of macrophytes in two distinct biogeographical regions of Central Europe. Knowl Manag Aquat Ecosyst 411: 09.

Kolada A. 2010. The use of aquatic vegetation in lake assessment: testing the sensitivity of macrophyte metrics to anthropogenic pressures and water quality. Hydrobiologia 656: 133-147.

Kolada A. 2016. The use of helophytes in assessing eutrophication of temperate lowland lakes: added value? Aquat Bot 129: 44-54.

Krolová M, Č́ž́ková H, Hejzlar J, Poláková S. 2013. Response of littoral macrophytes to water level fluctuations in a storage reservoir. Knowl Manag Aquat Ecosyst 408: 07.

Lacoul P, Freedman B. 2006. Environmental influences on aquatic plants in freshwater ecosystems. Environ Rev 14: 89-136.

Landucci F, Tichý L, Šumberová K, Chytrý M. 2015. Formalized classification of species-poor vegetation: a proposal of a consistent protocol for aquatic vegetation. J Veg Sci 26: 791-803.

Lauridsen TL, Jeppesen E, Declerck SAJ, De Meester L, Conde-Porcuna JM, Rommens W, Brucet S. 2015. The importance of environmental variables for submerged macrophyte community assemblages and coverage in shallow lakes: differences between northern and southern Europe. Hydrobiologia 744: 49-61.

Marhold K, Hindák F. 1998. Checklist of Non-vascular and Vascular Plants of Slovakia. Bratislava: Veda, 687 p.

McCullagh P, Nelder JA. 1989. Generalized Linear Models, second edition. London: Chapman \& Hall, 532 p.

Miklós L. 2002. Atlas Krajiny Slovenskej Republiky. 1. vydanie (Landscape Atlas of Slovakia, first edition). Banská Bystrica:
Ministerstvo životného prostredia Slovenskej republiky, Bratislava \& Slovenská agentúra životného prostredia, 342 p.

Novikmec M, Hamerník L, Kočický D, Hrivnák R, Kochjarová J, Otahel'ová H, Pal'ove-Balang P, Svitok M. 2016. Ponds and their catchments: size relationships and influence of land use across multiple spatial scales. Hydrobiologia 774: 155-166.

Oksanen J, Blanchet FG, Kindt R, Legendre P, Minchin PR, O'Hara RB, Simpson GL, Solymos P, Stevens MHH, Wagner H. 2016. vegan: Community Ecology Package. R package version 2. 3-3. http://CRAN.R-project.org/package=vegan.

R Core Team. 2016. R: A language and environment for statistical computing. R Foundation for Statistical Computing, Vienna, Austria. URL https://www.R-project.org/.

Riis T, Biggs J, Flanagan M. 2003. Seasonal changes in macrophyte biomass in South Island lowland streams, New Zealand. NZ J Mar Freshwater Res 37: 381-388.

Riis T, Olesen B, Clayton JS, Lambertini C, Brix H, Sorrell B. 2012. Growth and morphology in relation to temperature and light availability during the establishment of three invasive aquatic plant species. Aquat Bot 102: 56-64.

Sand-Jensen K, Borum J. 1991. Interactions among phytoplankton, periphyton and macrophytes in temperate freshwaters and estuaries. Aquat Bot 41: 137-175.

Sand-Jensen K, Pedersen NL, Thorsgaard I, Moeslund B, Borum J, Brodersen KP. 2008. 100 years of vegetation decline and recovery in Lake Fure, Denmark. J Ecol 96: 260-271.

Scheffer M, Hosper SH, Meijer M-L., Moss B, Jeppesen E. 1993. Alternative equilibria in shallow lakes. Trends Ecol Evol 8: 275-279.

Søndergaard M, Jeppesen E, Peder-Jensen J, Amsinck SL. 2005. Water Framework Directive: ecological classification of Danish lakes. J Appl Ecol 42: 616-629.

Stendera S, Adrian R, Bonada N, Canedo-Argüelles M, Hugueny B, Januschke K, Pletterbauer F, Hering D. 2012. Drivers and stressors of freshwater biodiversity patterns across different ecosystems and scales: a review. Hydrobiologia 696: 1-28.

Svitok M, Hrivnák R, Kochjarová J, Otahel’ová H, Pal'ove-Balang P. 2016. Environmental thresholds and predictors of macrophyte species richness in aquatic habitats in central Europe. Folia Geobot 51: 227-238.

Toivonen H, Huttunen P. 1995. Aquatic macrophytes and ecological gradients in 57 small lakes in southern Finland. Aquat Bot 51: 197-221.

Varanka S, Luoto M. 2012. Environmental determinants of water quality in boreal rivers based on partitioning methods. River Res Appl 28: 1034-1046.

Weisner SEB, Strand JA, Sandesten H. 1997. Mechanisms regulating abundance of submerged vegetation in shallow eutrophic lakes. Oecologica 109: 592-599.

Welch NH, Butler MG, Cerlson TJ, Hadson MA. 2003. Changes in macrophyte community structure in Lake Christina (Minnesota), a large shallow lake, following biomanipulation. Aquat Bot 75: 323-337.

Wheeler B, Torchiano M. 2016. lmPerm: Permutation tests for linear models. $\mathrm{R}$ package version 2.1. 0 .

Williams P, Whitfield M, Biggs J, Bray S, Fox G, Nicolet P, Sear D. 2004. Comparative diversity of rivers, streams, ditches and ponds in an agricultural landscape in Southern England. Biol Conserv 115: $329-341$

Cite this article as: Bubíková K, Hrivnák R. 2018. Relationships of macrophyte species richness and environment in different water body types in the Central European region. Ann. Limnol. - Int. J. Lim. 54: 35 